\title{
Developing Full Day School Model Based on Multiple Intelligences at Primary School Level
}

\author{
${ }^{1 s t}$ Muh. Luqman Arifin \\ Faculty of Education, UniversitasPeradaban, Indonesia \\ luq_c2003@yahoo.com
}

\begin{abstract}
This study aimed/aims to find out a learning model that allowed students to develop a multiple intelligence of/at full day school system at/in the primary school level. The study used Research \& Development Method which served to cultivate and validate the prototypes. The study sample was principals, teachers, and students from the three schools that applied full day school system in Brebes, Central Java. The data were collected by using observation and interviews, as well as document study/analysis in schools. The result of the research is a full day school model design consisting of input components (aptitude and interest tests), processes (full day school curricular and choreicular design), and output (multiple intelligence).
\end{abstract}

Keywords: Full Day School, Multiple Intelligence, Primary School

\section{INTRODUCTION}

The presence of schools implementing a full day school system in Indonesia is continuously increasing. 18 primary schools in Brebes, have implemented the system. Thus, in national level, there must be more primary schools inplementing the system since the full day school has already come to Indonesia in 1990s innitiated by the private Islamic-based primary schools known with the term "superior school"(in Indonesia called 'sekolahunggulan') (Sismanto, 2007).

Due to the recent increasing trend, the Ministry of Education andCulture, Muhadjir Effendy,through the Minister Regulation No. 23 Year 2017, wouldlike to implementthe system at theschools in Indonesia. 500 schools will be selected to become the piloting schools to implement the system and ifconsidered successful, the system will be massively implemented to all schools.

There are some reasons why this system will be officially implemented to schools in Indonesia. Beside minimizing the negative impacts from outside of the school environment, through this program the students' activities may also be well directed, stenghtened with character education usually containing skills, manners, sports, arts and cultures. Furthermore, Elicker and Mathur (1997) have found that children who attended full-day programmes were rated as having slightly more positive

\author{
${ }^{2 n d}$ Umi Chabibatus Zahro \\ Faculty of Education, UniversitasPeradaban, Indonesia \\ umi.sy@gmail.com
}

effect and better work habit scores than children attending half-day programmes".

Full day school model is based on multiple intelligences, an idea of school learning model concerning on the activation and optimization ofstudents' integences. The concept of multiple intellegences emphasizes on theuniqueness of each student. Each student is believed having strengths that there is no student considered stupid. As quoted by Colin Rose and Malcom J. Nicholl (2002: 57), Gardner in his theory states that each individual hasvarious intellegences, yet the development level is different from one to the others. Thus, with the existance of this full day system based on multiple intelligences, it is expected to produce uniquestudents with distinguising intelligences based on their potentials.

According to H. Baharudin, full day school system is considered as a long school day as the learning process starts at 6.45 a.m. - 3 p.m. with every two-hour break time. Wiwik Sulistyaningsing in Utomo (2017: 63) categorize this system as school with the character of integrated activity and integrated curriculum. Integrated activity means that all students' activities at school is wholly packaged in learning, playing, eating, and praying within an educational system that the students may obtain the whole and integrated materials containing the cognitive, affective and psychomotoric aspects. Meanwhile, Wolfinger inHernawan (2014: 4) states that integrated curriculum is a curriculum combining some scientific disciplines by mixing the contents, skills and attitudes. This process may result in the students' outcomesconsisting learn to know, learn to do, learn to live together, and learn to be.

By spending the time approximatelyfor nine hours a day including the break time during the learning process, it is not easy for the students. To well package the integrated activity and integrated curriculumwith the sophisticated result, indepth learning formula is necessary to conduct.

The concept development of multiple intelligences may become one alternative answer to offer. Many teachers still think that there is only one intelligence type. A student is considered clever if s/he has a high IQ level. Meanwhile, according to neurologists, intelligenceis 
not only limited to IQ. Thus, thestudents are necessary to obtain education based on the educational purposes. Bloom and Krath Wohl state that education should be able to change three aspects: cognitive, affective and psychomotoric aspects.

\section{METHODS}

This qualitative research type is conducted based on R\&D (Research and Development) method. The research is conducted in two stages, referring to the $R \& D$ method. Borg \& Gall (1983: 775) explain that the first stage is introductorystudy to obtain the necessary information through literature study, observation, and interview, while the second stage is product design. The data are obtained through observation and interview with the teachers and students of three islamic primary schools implementing full day school system in South Brebes Regency: SD IT Al-Anbari, SD TQ Al-Ikhlas, and SD IT HarapanUmat.

\section{RESULTS AND DISCUSSION}

The result obtained from the stage of preliminary study, full day system implemented at school partly has no learning design based on multiple intelligences starting when the students are first admitted at untill graduated from school. Some have implemented the system and design, such as conducting interest and talent test, yet not utilized to support the learning processes.

Integrated design is considered important. Gagne in Gredeer and Margaret (1986:121) explain that learning covers three components: internal (internal conditions of learning), external (external conditions of learning), outcomes (outcomes of learning), or may be simplified into input, process, until output stages.

Input stage is the stage of each prospective student to join the interest and telent test to know his/her intelligence tendency. The test result will be used as recommendation and material in learning processes that the students may obtain the proper learning method meeting their talent and interest. Output stage is related to the development of students' intelligance type in meeting their talent and interest.

Thus, it is important to formulate a product in the form of a full day schoolmodel design based on multiple intelligence covering input, process, and output stage.

\section{a. Input}

Input process test is considered important as each prospective student undeniably has different intelligence tendency. Furthermore, Deary, I. J., Penke, L., \& Johnson, W. (2010) state that even sex may differ someone's intelligence.

The interest and talent test is objective, explaining the students' actual competence as well as avoiding the unexpected "desire" both from the perspective of students and parents. The "desire" sometimes coming from either the students or parents who force their children to be highly competent in certain field should be anticipated. There is no such condition that a research shows that approximately $40 \%$ talented students at schools fail to obtain any achievement regarding to their actual posessed capacity (Lucy, 2010). Muhibbin (2009:145) revealsthat the level of students' achievement is influenced by two main factors. First, internal factors including Intellegence, attitude, talent, interest, motivation, and learning style. Second, external factors including family, school, and society. The test is not only for the students, but also teachers to help them recognize the students' learning style. Felder and Silverman (1988) suggest some teaching styles (instructional method and so forth) to provide more benefits to the teachers related to their learning styles.

\section{b. Process}

Process is the implementation of learning, counseling, andtraining activities by utilizing various media, strategies, and facilities to reach the learning objectives. Learning process in full day system starts at 7 a.m. to 3 p.m. (Hasan, 2012: 100). In learning process, there are some components to fulfill: curricular and cocurricular activities, teachers, infrastructures and facilities. Process standard refers to the Regulation of Minister of National Education No. 41 Year 2007 on November 23, 2007 concerning on process standard for the Primary and Secondary Educational Unit, covering the learning process planningwhich has to completely fulfill the SemesterLearning Plan (in Indonesia known as RencanaPembalajaran Semester or $R P P$ ).

The Semester Learning Plan (RPP) is not only prepared for the lessons included in curricular program, which lessons are commonly determined by the government or school institutions, butalso covers all activities provided by the school, such as thoseincuded into extracurricular.

Kunandar (2007: 177) states that extracurricular programs include intracurricular which consists of self development activities mosty conducted inthe class, while co-curricular or extracurricularis a series of teachinglearning process activity programs outside of the time allotted for the programmed lessons to improve untuk the students logical thinking insights, grow their talents and interests as well as the spirit to conduct various community services.

In the intracurricular activities, the learning process has to be able to accommodate thestudents' intelligence, such as in Natural Science Lesson, learning with the materials onplants, the teacher should explain the materials while singging since the students are interested in music. Furthermore, Hastuti (2008:63) explainsthat extracurricular isthestudents' channels to show and improve their talents ans interests, competences, and skills such as memorizingthe Holy Qur'an (tahfizh), sports, arts, sciences, mathematics, drama, theatre, and scoutactivities. Thus, the extraculicular activity forms should also provide various choices and accomodate various types of intellegence. 
Teacher as a process element should also possess individual, professional, pedagogical, and social competences to deal with the complexity of students' intelegence. The learning conducted by the teachers should accomodate and provide spaces for each student's competences. Thus, teachers should plan the development strategiesfor the students' intelligence bydesigning andimplement various activities selected by the students themselves in accordance with their intelligence indicators.

In addition, to successfully support the full day school system, the related schools should be supported with adequate infrastructures and facilities as standardized in the Regulation of the Ministry of National Education of the republic of Indonesia No. 24 Year 2007 covering the minimum area of land, building floor, classroom, laboratory, sports center, praying site, library, types of reading books, education media, Natural Science laboratory, and other supporting equipment must be possessed by the related schools.

The Schools' Complete Facilities and Infrastructures may ease the sudents and the occuring learning processes. This is in accordance with the opinions stated by Khairani in Siti Ambarwati (2014:10-11) mentioning that learning facilities arecompulsory media to support the students' learning interests. Inadequate or inexistance of learning facilities may directly create the students' laziness conditions to learn. Formal education and learning are greatly influenced by some components including raw input (student), instrumental input (learning materials, method, media, facilities and infrastructures), and inviromental input (physical, social, and cultural environment). The learning system Integrated components greatly determine the result of learning.

\section{c. Output}

More completed component is greatly required in order to provide outputs or outcomes well resulted from the learning processes, such as good academic competence, personal competence, and social competence, in the form of nine intelligences covering linguistic, logical mathematic, musical, interpersonal, intrapersonal, naturalist, spatial (visual or pictural), and kinestetic competence.

Thus, the figure of input design, process, and output may be seen from the following scheme.

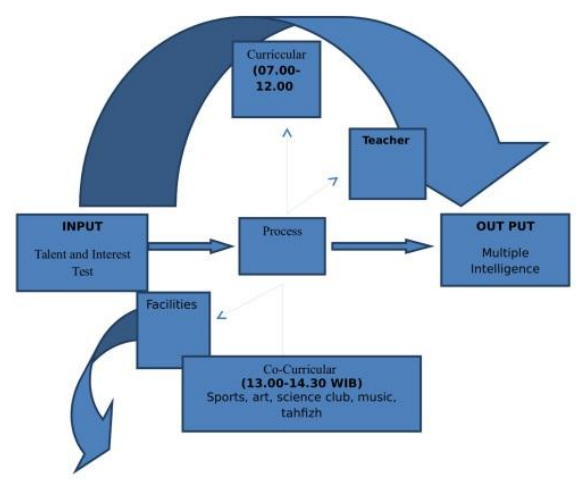

\section{CONCLUSION}

The research result shows the full day model design consisting of input components (talent and interest test), process (full day school curriccular and co-curricular design), and output (multiple intelligance) to develop the students' multipleintelligance at primary school level based on their talents and interests.

\section{REFERENCES}

Ambarwati, Siti. 2014. Pengaruh Sarana Belajar Terhadap Hasil Belajar siswa pada Mata Pelajaran Ekonomi di MAN 2. Skripsi, Pontianak: FKIP UNTAN

Borg, W.R. \& Gall, M.D. 1983. Educational Research: Longman, New York London

Colin Rose dan Malcom J. Nicholl. 2002. Accelerated Learning For the 21st Century, Cara Belajar Cepat $X X I$. Bandung: Nuansa.

Deary, I. J., Penke, L., \& Johnson, W. 2010. The neuroscience of human intelligence differences. Nature reviews neuroscience, 11(3), 201.

Elicker, J., \&Mathur, S. 1997. What do they do all day? Comprehensive evaluation of a full day kindergarten. Early Childhood Research Quarterly, 12(4), 459-480.

Felder, R. M., \& Silverman, L. K. 1988. Learning and teaching styles in engineering education. Engineering Education, 78(7), 674-681.

Gredeer, B., dan Margaret, E. 1986. Learning and Instruction: Theory into Practice. New York: Macmillan Publising

Hastuti, T.A. 2008.Kontribusi Ekstrakurikuler Bolabasket Terhadap Pembibitan Atlet dan Peningkatan Kesegaran Jasmani. Jurnal Pendidikan Jasmani 
Indonesia. Jurusan Pendidikan Olahraga. Fakultas Ilmu Keolahragaan.

Hernawan, A. H., \& Resmini, N. 2014. Pembelajaran Terpadu di SD.

Kunandar. 2007. Guru Profesional Implementasi Kurikulum Tingkat Satuan Pendidikan (KTSP) dan Sukses Dalam Sertifikasi Guru. Jakarta: Rafa Grafindo Persada.

Lucy, Bunda. 2010. Mendidik Sesuai Minat dan Bakat Anak ( Painting Your Children's Future). Jakarta: PT.Tangga Pustaka.

Muhibbin, Syah. 2009. Psikologi Belajar. Bandung: PT Remaja Rosdakarya.

N. Hasan, "Education, young islamists and integrated islamic schools in indonesia," J. Studialslamika, Vol. 19, no. 1, 2012, 100

Sismanto. 2007. Awal Munculnya Sekolah Unggulan, 'Artikel'.

Utomo, T. P. 2017. Meningkatkan Prestasi Peserta Didik Melalui Pendidikan Full Day School. AlAsasiyya: Journal Of Basic Education, 1(1). 